\title{
Jews of Sarajevo and Their Place in the Ottoman Society of Bosnia
}

\begin{abstract}
Aladin Husić*
Abstract

The first reports about presence of Jews in Sarajevo are dated to the middle of $16^{\text {th }}$ century since when they started gradually to integrate into economic and social streams in Sarajevo and Bosnia. It is very probable that they initially were settling on individual basis as merchants and just only from the beginning of $17^{\text {th }}$ century they start to settle with families and organize as residential community. Choosing of Sarajevo was also a result of pressure that was imposed upon Jews in Dubrovnik, Venice and other merchant places of the West. Since then reports about Jews in Bosnia and their activities are more frequent, and in $17^{\text {th }}$ century they constituted a distinguished economic community in Sarajevo with significant investment in business connection to Dubrovnik and Venice. Their primary occupation in relations with the West was trade followed by banking business. Research results show that at least $22 \%$ of Jews in Sarajevo performed some kind of trade, what is very high percentage if we take into account size of the community. This enabled Jews to position themselves in the most elite part of Sarajevo and they are the only social community that as a whole has lived in the most elite economic and professional area of the city. Towards the end of Ottoman rule, Jews of Sarajevo have been transformed into very respectable community that had $9 \%$ of share in the whole population of the city. Analysing some sources we see that they used $30 \%$ of storerooms and $16 \%$ of shops in the biggest trading buildings what additionally shows how important was their share in the economy of the city.
\end{abstract}

Keywords: Sarajevo, Jews, trade, economy, society.

* Dr., University of Sarajevo, Institute of Oriental Studies, Sarajevo/BOSNIA and HERZEGOVINA, aladinhusic@hotmail.com ORCID: 0000-0003-2000-1222

DOI: 10.37879/belleten.2020.1097

Makale Gönderim Tarihi: 06.06.2017 - Makale Kabul Tarihi: 11.08.2020

Belleten, Aralık 2020, Cilt: 84/Sayı: 301; 1097-1114 


\title{
Saraybosna Yahudileri ve Bosna'da, Osmanlı Toplumu İçerisindeki Yerleri
}

\begin{abstract}
$\ddot{\mathbf{O} z}$
Saraybosna'da Yahudilerin varlığına dair ilk bilgiler onların Bosna ve Saraybosna'daki ekonomik ve sosyal yapıya yavaş yavaş entegre olmaya başladıkları dönem olan 16 . yüzyılın ortalarına kadar uzanır. Başlangıçta muhtemelen tüccar olarak bireysel düzeyde bölgede Yahudilerin yerleşimi olmuşsa da 17. yüzyılın başlarından itibaren aile düzeyinde yerleşik bir cemaat olarak iskân etmeye başlamışlardır. Saraybosna'nın tercih edilmesi Dubrovnik, Venedik ve batıdaki diğer ticaret merkezlerinde Yahudiler üzerindeki baskının bir sonucudur. O dönemden beri, Bosna'daki Yahudiler ve onların faaliyetleri hakkındaki haberler daha sık görülür hâle gelmiş ve tam olarak 17. yüzyılda Dubrovnik ve Venedik ile ticari iş bağlantılarında Saraybosna'da tanınan, çok önemli bir role sahip ekonomik topluluk hâline gelmişlerdir. Batı ile ilişkilerinde birincil uğraş noktaları ticaret ve bunun ardından bankacılık olmuştur. Araştırmalar, Saraybosna'daki Yahudilerin en az \% 22'sinin ticaret ile uğraştı̆̆ını gösteriyor ki bu topluluğun genel oranı dikkate alındığında yüksek bir sayı olarak karşımıza çıkmaktadır. Bu durum Yahudilerin Saraybosna'nın en elit kesiminde yer almalarını ve şehrin tüm seçkin ekonomi ve zanaat kesimlerinde yaşayan tek sosyal topluluk olmalarını sağlamıştır. Osmanlı yönetiminin sonuna kadar Saraybosna Yahudileri şehir nüfusunun \% 9'una tekabül eden saygın bir cemaat hâline geldiler. Bazı kaynakların analizinde onların en büyük ticari tesisler içerisinde yer alan ambarların \% 30'unu dükkânların ise \% 16’sını kullandıklarını göstermektedir ve bu oran şehrin ekonomisine ne kadar katkı sağladıklarına tanıklık etmektedir.
\end{abstract}

Anahtar Kelimeler: Saraybosna, Yahudiler, Ticaret, Ekonomi, Toplum.

\section{First Sources Accounts Mentioning Jews In Sarajevo}

It is still not possible to precisely determine, on the basis of historical sources, when and in what number Jews began to settle in Sarajevo. We are still left with generalized assumptions and deduced conclusions, some of which, without firm basis, place them to year $1541 .{ }^{1}$ While on the other hand, some sources undouble confirm their existence in Sarajevo, but place it in other dates after 1550.

1 This year was mentioned at Moša (Rafael) - Zeki Efendi’s study, and was largely used by many other researchers. The source on which this information was based is a "written book that I managed to get from an old Turkish library". Therefore, is not possible to verify this information today. According to: Muhamed Nezirović, "Historija bosanskih Jevreja Moše (Rafaela) Atijasa Zeki Efendije", Prilozi, Institut za istoriju, 29 (2000) Sarajevo 2000, p. 252. (245-260); Moric Levi, Sefardi u Bosni, Beograd 1969, p. 10. 
Jews of Sarajevo and Their Place in the Ottoman Society of Bosnia 1099

Merchant activities performed by Jews have been documented in judicial records (sidjil) of Sarajevo repeatedly through years $\left(1557,1565\right.$, and 1566). ${ }^{2}$ From those activities we learn about participants, trading goods and trading directions. However, basic questions such as when and in what number they began to arrive, are still to be answered. What we can understand from examined records is that their initial number of Jews was not large. Even when it is taken into consideration that the recorded cases were only actual court cases, that impression does not change much. An additional argument for confirmation of the impression would be low circulation of money, meaning that amounts of money documented throughout these cases were small, leading us to the conclusion that the Jews were on the beginning of their trading activity. Apart from the mentioned indications from mid- $16^{\text {th }}$ century, it is quite surprising that other familiar Ottoman sources do not mention Jews in Sarajevo until the end of the century. It is particularly strange that rich Ottoman sources from 1560s and 1570s containing lists of households in Sarajevo have no records of Jewish households. ${ }^{3}$ A possible explanation why the Jews were not recorded in Ottoman extensive censuses could be that they lived in collective lodgings in the city. Another possibility is, since there were not many of them and since they were very mobile, that they would temporarily leave the city for business purposes. Sources from Dubrovnik contain recorded activities of Jewish merchants from Sarajevo on Dubrovnik-Sarajevo routes, right after the period of 1560-1570s. From 1570 onwards more frequent accounts appear compared to what we had in their first records in Ottoman sources, especially in sidjils. Apart from more frequent trading activities, trading transactions were much larger than what was recorded before. It is also indicative and very interesting that some individuals were recorded as residents of many different places. Mojsije Kuzina, for example, is being referred to as "a Jew from Sarajevo" in one source and "a resident of Mostar" in another. ${ }^{4}$ This situation would be consistent with the assumption of their possible temporary town leaving for business purposes in coastal cities or around that area. It is however obvious that any kind of pressure or insecurity in Dubrovnik or Venetian Republic would result in increased frequency of documented activities where the subjects would be referred to as "the Jews of Sarajevo". It means that if any pressure and insecurity occurred, they would withdraw towards Sarajevo or Ottoman Empire, where they traditionally were well

2 Sarajevo, Gazi Husrev-begova biblioteka, Sidžil 1 and 1a, 2.

3 Istanbul, BOA, TD, 379.

4 Jorjo Tadić, Fevreji u Dubrovniku do polovine XVII stoljeća, Sarajevo 1937, p. 203. 
accepted. This was obvious after the outbreak of war between Ottoman Empire and Venetian Republic (1570) which also caused prosecution of Jews in Venetian territories, then was followed with famous trial to the Jewish merchant Izak Ješurin in Dubrovnik (1622) and finally cumulating with imposition of custom duties (1637) in Dubrovnik. ${ }^{5}$ Such dire circumstances had pushed Jewish merchants towards Sarajevo. Yet, from all these documented records, it is still not possible to determine the approximate number of Jewish settlers in the city. Even information about Sijavuş Pasha's khan is not helpful and it is insufficient. Furthermore, it even complicates solving this question. So far, the researchers agreed that it was year 1581 when the khan was built. The document that gave basis for questioning the building of khan in that year has rarely been critically reviewed. It was rather accepted as authentic, and with such presumptions, wrong conclusions were delivered. The document was finally brought to critical analyses by Alija Bejtić who found some doubtful situations relating to the text about Sijavuş Pasha's khan ${ }^{6}$ It was obvious that the text about Sijavuş Pasha's khan was inscribed retrospectively into the source from the beginning of $18^{\text {th }}$ century (1727-28), and that this source was a basis for all information regarding the building of Sijavuş Pasha's khan. Even the content of the inserted text is disputable as it has no characteristics of an official document. Moreover, it rather resembles an oral tradition. To all these doubts, there is also another one; the document speaks about Jews as "poor" while it is actually quite clear from sources dated to $16^{\text {th }}$ century, and especially of those before 1580, that they were merchants and successful businessmen. The poverty cannot be in question, at least not in that period. In a manner of speaking it is still not possible to get a clearer picture of the demographic potential of Jews in $16^{\text {th }}$ century.

\section{A Few Demographic Indicators}

The first source that is initial point for discussion of demographical indicators mentioning "Jewish community" in Sarajevo is dated to 1604. Contrary to all expectations this record documented only three representatives of their households:

5 J. Tadić, Fevrëi u Dubrovniku, p. 210.

6 Alija Bejtić, "Jevrejske nastambe u Sarajevu“, Spomenica, 400 godina od dolaska Jevreja u Sarajevo, Jevrejska zajednica Sarajevo 1967, p. 26; Alija Bejtić, "Sijavuš-pašina daira“, Prilozi za proučavanje istorije Sarajeva, Godina II, Knjiga II, Sarajevo 1966, pp. 66-67. 
Jews of Sarajevo and Their Place in the Ottoman Society of Bosnia 1101

Mošiko Yehuda, Solomon Yehuda and Aslan Yehuda. ${ }^{7}$ That fact is not compatible with many previous statements about Jews of Sarajevo from $16^{\text {th }}$ century. For now, it is not possible to determine whether these were actual representatives of the larger community or perhaps the document indeed did not mention the Jewish population because of their immigration. However, at the moment we do not have the exact answer to that question. This could be the result of insecurity for Jews that archbishop from Split, Marc Antonio, wrote about in his report from 1603. ${ }^{8}$ On the other side, the later resources, present the larger number of Jews than it was documented in 1604, and generally mention the new cases of immigration.

Eighteen Jewish merchants were mentioned as signatories of one remonstrance during 1607 in Sarajevo. ${ }^{9}$ That could represent the approximate number of families present in Sarajevo at that time, or at least a small part of the total number. Nevertheless, we should not exclude a possibility that those were single merchants - without families. There was also some news that spoke about 30-40 families from Constantinople and Salonica settling in Sarajevo during $17^{\text {th }}$ century ${ }^{10}$ In literature, different years can be found that mark their arrival (in 1604 or 1614) but none of these mentioned years corresponds to the period of reign of Bosniak Baltadži Mehmed Pasha (1620-1621). Therefore, it must have happened somewhat later. According to Zeki Efendi, the news was about those who had left Sarajevo earlier. $^{11}$

Even though trading activities of Jews from Sarajevo were more frequent in $17^{\text {th }}$ century, the sources of that period still do not provide us with more certain data of the number of Jews. Atanasije Grgičević had given information that brings us to a conclusion that Jews were settled in a sort of a collective lodging: "there is one saray for Fewes encompassed with a big wall". ${ }^{12}$ The other reports from Pavlo Rovinjanin

7 Opširni popis Bosanskog sandžaka iz 1604, Sv. I/1, Obradio: Adem Handžić, Sarajevo 2000, p. 91.

8 Karlo Horvat, "Novi historijski spomenici“, GZM, Sarajevo 1909, 104.

9 Jorjo Tadić, "Doprinos Jevreja trgovini sa dalmatinskim primorjem u XVI i XVII vijeku", Spomenica 400 godina dolaska Jevreja u BiH, Jevrejska zejednica, Sarajevo 1976, p. 44.

10 M. Levi, Sefardi u Bosni, 11; Muhamed Nezirović, "Historija bosanskih Jevreja Moše (Rafaela) Atijasa - Zeki Efendije ", Prilozi, Institut za istoriju, 29 (2000) Sarajevo, 2000, pp. 253-54.

11 M. Nezirović, "Historija Bosanskih Jevreja Moše (Rafaela) Atijasa-Zeki Efendije", pp. 253-254. There are some disagreements about the exact years but it is obvious they speak about the same event.

12 Mijo V. Batinić, "Nekoliko priloga k bosanskoj crkvenoj povijesti", Starine $7 A Z U$ XVII, Zagreb 1885, p. 127. 
(1640) Marijan Maravić (1655) or Poulet (1658) just mentioned them without any detailed information about their number. ${ }^{13}$ Yet, Evlija Çelebi (1659) and Nikola Olovčić (1672) were more precise. Çelebi talks about "two neighbourhoods of Jews" and Olovčić mentioned "one hundred Jewish houses". Both data are different and they are not contradictory. Moreover, there is an agreement in one more aspect of Jewish life: they both mentioned synagogue which is new in comparison to other sources. ${ }^{14}$ These are the most comprehensive news about Jews in Sarajevo we have come across so far. Some sources mentioned the arrival of Jews from Buda after 1686. Even if some Jewish sources indicate the same, this information cannot be verified in any other sources nor can it be traced completely. The only detail we could confirm was arrival of Haham Gevi Aškenazi from Buda. ${ }^{15}$ According to Muvekkit, a caravansary was built for the needs of Jewish refugees from Buda, on waqf of Gazi Husrev Bey. That building he referred to as Mahmud Khan; had 48 rooms. ${ }^{16}$ The particular case Muvekkit wrote about cannot completely be verified by the information Cevi Aškenazi gave us or by some other Ottoman sources. However, couple of years after the conquest of Buda, one Ottoman source from 1690 spoke about 70 Jewish men. This information also does not correspond to some other earlier data, such as that of Olovčić and Muvekkit. The only way this case could be explained is that the Jews in Sarajevo for some reason did not have to pay poll tax (jizya) for that year, therefore they were not documented. Although the source did not state that, nor it explained why it was so. From the number of documented Jews, we can partially figure out their social status. Most of them $(75 \%)$ paid the lowest amount of poll tax, 14\% paid the middle amount and $11 \%$ paid the highest amount. That means that majority (of Jews) were of poor financial status. Even though that number cannot possibly correspond to the number of families, we can at least take it as the lower limit of actual number of Jewish

13 Stipan Zlatović, "Izvještaj o Bosni god 1640. O. Pavla iz Rovinja“, Starine 23, 36-38.; F.(ran) M.(ilobar), "Dva savremena izvještaja o Bosni iz prve polovine XVII. stoljeća", GZM, XVI./1904, Sarajevo, 1906, p. 253; Vjekoslav Jelavić, "Doživljaji Francuza Poullet-a, na putu kroz Dubrovnik za Bosnu, (godine 1658)“ GZM 1908, Sarajevo 1908, pp. 56-71.

14 Evlija Čelebija, Putopis, odlomci o jugoslovenskim zemljama, (Preveo, uvod i komentar napisao Hazim Šabanović, Sarajevo, 1979. 105-106, p. 118; Julijan Jelenić, Spomenici kulturnoga rada bosanskih franjevaca, Starine XXXV, (1918), Zagreb 1916, p. 138

15 M. Levi, Sefardi u Bosni, 20-21; ShlomoJ. Spitzer - Komoróczy Géza, Heber Kútforrások Magyarország és a magyarországi zsidóság történetéhez a kezdetektől 1686-ig, MTA Judaiszitakai Kutatócsoport - Osiris Kiadó, Budapest 2003, pp. 777, 781-782.

16 Salih Sidki Hadžihuseinović, Muvekkit, Povïjest Bosne 1, Sarajevo 1999., p. 403.; V. Skarić, Izabrana djela, I, p. 126. 
Jews of Sarajevo and Their Place in the Ottoman Society of Bosnia 1103

households. What we can also see are the locations from which they arrive. Two families came from Belgrade, two from Stari Vlah and they are marked as "merchant". ${ }^{17}$ In a source from 1696 there were 64 adult Jewish men documented. ${ }^{18}$ A tax list (sorted by names) of one Jewish district from 1725 had 65 family names on it. This partially corresponds with what was documented in 1690 by Ottoman sources. According to these data, we can state that the number of Jews in Sarajevo at the end of $17^{\text {th }}$ and beginning of $18^{\text {th }}$ centuries could have between 350 and 500 individuals. Although the sources which we could use to track demographical growth of Jews are rare, we could still say on the basis of available ones, that in $18^{\text {th }}$ century their demographical growth was high. It is not possible to determine the reason of that growth, since both of the factors, natural increase and immigration, could be equally relevant. Jewish sources in 1779 documented 214 families in Sarajevo, so it could be assumed that the number of Jews could be $1077 .{ }^{19}$ Of course, all of the above presented data are only cases that had been documented, and as such, we can observe them as the lower limit of number of Jewish population in Sarajevo. Later sources, from the $19^{\text {th }}$ century, show how these data were not far from the real state. French captain Roux la Mazelier estimated that there were 200 Jewish families living in Sarajevo in 1807-9. ${ }^{20}$ The most precise data about Jews in Sarajevo we get from Mula Mustafa Mestvica in $1841 .{ }^{21}$ Mestvica registered male Jewish population completely, both young and adults. He documented 242 Jewish households with 738 male members. If we consider that this represents a half of the total Jewish population, then it can be concluded that their number could be around 1500 individuals. Later estimations (1851-1865) range from 1714 to 3673 individuals in Sarajevo. ${ }^{22}$ First number can be accepted as a real growth and the other one $(3673)^{23}$ was a clear obvious oversight, and it is an unreal number of population based on an assumption of their natural and mechanical growth. Such

17 BOA, MAD, 1439.

18 BOA, MAD, 1214 and one poll tax census which is not enumerated.

19 M. Levi, Sefardi u Bosni, p. 23.

20 V. Skarić, Izabrana djela, II, 234.

21 Mula Mustafa Mestvica, Popis uzajamnog jamčenja stanovništva u Sarajevu iz 1841. godine, (preveo s turskog: Derviš Korkut) Sarajevo 1970., pp. 371-400; Derviš M. Korkut, "Mestvičina ćefilema iz 1841 “., Prilozi za proučavanje istorije Sarajeva, II, Sarajevo 1966, pp. 115-116.

22 Slavko Kaluđerčić, "Iz istorije Sarajeva“, Glasnik Jugoslovenskog profesorskog društva, knj. XIX, sv. 1112, Beograd 1939., pp. 844-845; Hana Younis, "Skice porodičnog života u Sarajevu posljednjih decenija osmanske vladavine", Prilozi, 36, Sarajevo 2007, pp. 35-36.

23 Đorđe Pejanović, Stanovništvo Bosne i Hercegovine, Beograd 1955. 
misinterpretations were represented in later sources. Official census from 1879 documented 2077 Jews. ${ }^{24}$ In mid- $19^{\text {th }}$ century Jews counted $9 \%$ of the total population of Sarajevo.

\section{Settlement Disposition of Jews in Sarajevo}

The overview of Jewish dwellings was studied by Alija Bejtić, especially from viewpoint of urban position and placements of neighbourhoods in $19^{\text {th }}$ century. On the basis of sources available to him, he reflected upon early information about settlement of Jews within the city. He particularly turned his attention to historical and architectural analyses of Sijavuş Pasha's khan. ${ }^{25}$ It is necessary to review certain statements on basis of some new indicators as well as to take into consideration some new details we came across.

Reflecting upon Jews, Vladimir Ćorović stated that first Jews in Sarajevo were not permanent residents, but they were single individuals who were returning back to their families in Salonica or other places from which they had come before. Zeki Efendi also noted that they "lived in city khans". ${ }^{26}$ Alija Bejtić assumes that in those early cases they had lived in collective lodging, like khans or big houses. That could be answer to previously asked question why sources rarely mentioned them, especially when we know that they were not represented in censuses of Sarajevo. A very first case that is documenting their settlement disposition in Sarajevo dates from 1565, where it is said that Isak son of Rafael lived in Sagrakdži Mahmud's neighbourhood. ${ }^{27}$ From that fact we cannot tell whether it was individual or collective housing unit. We mentioned that the sources of $17^{\text {th }}$ century do not provide precise indications, but generalized ones only, like "saray" or "two neighbourhoods". One of the two certainly refers to Sijavuş Pasha's khan. The other neighbourhood we should try to identify in what Alija Bejtić identified as -- the other collective accommodation in Sagrakdži Mahmud's neighbourhood. With this we solve another important dilemma. Muvekkit said that the Jews from Buda inhabited "Mahmud's khan". He identified it (or perhaps mistaken it?) with Sijavuş Pasha's khan. We can be certain that it was the collective lodging in

24 Štatistika miesta i pučanstva Bosne i Hercegovine, Sarajevo 1880, p. 3.

25 A. Bejtić, "Jevrejske nastambe u Sarajevu", 34-37; A. Bejtić, "Sijavuš-pašina daira", p. 79.

26 M. Nezirović, "Historija Bosanskih Jevreja Moše (Rafaela) Atijasa - Zeki Efendije“, p. 253.

27 GHb sidžil la; A. Bejtić, "Jevrejske nastambe u Sarajevu ", p. 23. According to the census from 1565 this neighbourhood had 40 married and 27 unmarried (single) men. Jews were not registered, neither in a neighbourhood's section nor separately. 
Jews of Sarajevo and Their Place in the Ottoman Society of Bosnia 1105

Sagrakdži Mahmud's neighbourhood that Muvekkit wrote about. In that way the two neighbourhoods that Çelebi wrote about were nothing other than two collective lodgings: Mahmud's khan (in Sagrakdži hadži Mahmud's neighbourhood) and Sijavus Pasha's khan. It has its affirmation in the fact that second half of $16^{\text {th }}$ century is richer with information about Jewish trading activities, especially after 1570. As information on Sijavuş Pasha's khan are still vague there are more details to reflect upon. Available sources from $17^{\text {th }}$ century mention the name "Beytï'lyahüd der Saraj" as something that was commonly identified with Sijavuş Pasha's endowment. The same source (1690) documents very low number of Jews who inhabited it, only 8 , therefore we assume that it is 8 families. Above all, they paid the highest amount of jizya tax, which indicates that they were rich rather than poor people. That leaves us with a question what happened with those refugees from Buda for whom it is told that they were also located in that collective lodging. For all others it is said only "tâife-i yahüd, der Saraj" without any indication on where they lived.

Only a few years later (1696), right before the invasion of Eugene of Savoy (1697), two different sources mentioned "mahalle-i Beytiïl-yahüd der Saraj". It referred to two neighbourhoods; the two previously mentioned collective lodgings where the Jews were located. At the same time, we can notice that Jews began to appear in other places and other neighbourhoods. For those years, there are records of individual residing of two families in Bardakčije. That is also the first known case of residing outside of the two known collective accommodations. In $18^{\text {th }}$ century number of Jews dwelling in other neighbourhoods will increase. In second half of $18^{\text {th }}$ century some sources mentioned individuals living in Careva mahala, close to present-day Careva Mosque; in Minedžin khan, in Kasim Kjatib's mahala. ${ }^{28}$ In these cases their status is not known; whether those were rented or collective lodging, or private objects. In late $18^{\text {th }}$ century there was a reference to another neighbourhood where Jews resided, called, Buzadži hadži Hasan's mahala”. The first known mention from 1793 tells us that a private property bordered with two Jewish residential buildings. ${ }^{29}$ Even if it was not precisely said, from later sources we see that even in that neighbourhood there was a collective accommodation, which would be the third one we know about. Two families lived individually, one in a private house and the other in a rented one, while the other six were sub-ten-

Mula Mustafa Bašeskija, Ljetopis, Sarajevo 1968, p. 117, 390.

29

"Yehudilerin mulk menzilleri".

Belleten, Aralık 2020, Cilt: 84/Sayı: 301; 1097-1114 
ants (kirajd žje), in one object. ${ }^{30}$ This information is also an indicator of concentrating Jews in one area of the city, in its best and the most important part.

The situation is clearer in first half of $19^{\text {th }}$ century. It is possible to define area that was populated by Jews. They were located in the most significant part of the town, in the centre of its economic part, on the west of the bazar (Çarşı) and Gazi Husrev Bey's endowments. Those were neighbourhoods: Pehlivan Oruç, Ferhat Paşa, Velika avlija, Hadži Kemal, Jagdži-zade, Husrev-beg and Buzadži hadži Hasan. The basis was obviously Sijavuş-pasa's khan. As it could be noted, dispersion is larger in the first phase of their early settling. During $17^{\text {th }}$ century they actually lived in two collective lodgings, Sagrakdži hadži Mahmud's neighbourhood/Mahmud's khan and Sijavuş Pasha's khan (bir hân-i kebîr - the big khan). Considering 17 $7^{\text {th }}$ century's information, it is clear why the other khan was called "the big khan". It could accommodate more people comparing to Mahmud's. In $18^{\text {th }}$ century, apart from Sijavuş Pasha's khan, Jews resided in other neighbourhoods, outside of the mentioned circle of six neighbourhoods. It is also interesting that later they were not present in the parts of the city where we find their residence being firstly documented. Those replacements happened at the end of $18^{\text {th }}$ century, probably after a few big fires. There were several fires occurred because of negligence: in Sijavuş Pasha's khan $(1746,1755)$ and in a private Jewish house (1788) not far away from the khan. The consequences of those fires were disastrous. ${ }^{31}$

\section{Social and Economic Activities of Jews}

Jews were engaged in trading ever since they come to Sarajevo. We learn about their presence by following the routes of their trading activities. It was not documented whether they were engaged in some other businesses apart from trading. Financial transactions indicate that apart from trading, the Jews could also be engaged in banking. The first reports provide us with information about small transactions, mostly cloth materials on relation Sarajevo - Dubrovnik or Sarajevo - Skopje. In second half of $16^{\text {th }}$ and $17^{\text {th }}$ century their trading network spread on other cities within borders of Ottoman empire, such as: Novi Pazar, Candia, Sofia, as well as to those outside of Ottoman borders; Venice, Ancona, Firenze,

30 A. Bejtić, "Jevrejske nastambe u Sarajevu“, pp. 28-29.

31 Vladislav Skarić, Sarajevo i njegova okolina od najstarïin vremena do Austrougarske okupacïje, Sarajevo 1937, p. 139. According to Skarić it happened on 25-26 ${ }^{\text {th }}$ of April, 1746. Muvekkit notes that it happened in 1748. (Muvekkit, Povijest Bosne 1, 515). 
Jews of Sarajevo and Their Place in the Ottoman Society of Bosnia 1107

Livorno, Split. The amounts of transactions had increased over the time, and the largest one that was documented was the one in 1592 that amounted 1200 ducats. At the beginning trading objects were mostly different kinds of cloth materials, later they included spices, leather, resin, clothes, rugs, wax, and wool. Apart from these activities, they had strong business connections, established and enforced with suitable family relations. Most of Jewish traders from Sarajevo had someone from their family, at least in Dubrovnik and even further across other trading centres. In some places they had special agents who assisted in exporting or importing of goods. The trade was the only documented economic activity of Jews during $16^{\text {th }}$ and $17^{\text {th }}$ centuries, but it does not mean it was the only one. At the end of $17^{\text {th }}$ century among residents of Sijavuş Pasha's khan, there were two merchants and one tin-artisan (kalaycı) from another Jewish neighbourhood.

From Jewish sources in $18^{\text {th }}$ century (1773), we learn that from Bosnia they exported wax and leather (sheep, goat, and rabbit). While list of imported goods is larger and includes: linen, silk, coffee, sugar, zinc, tin, glue, reset, steel, lead, wire, hemp, porcelain, glass, and paint. ${ }^{32}$ At the end of $18^{\text {th }}$ century there are some account about shops they leased to work in them. Bašeskija noticed nicely arranged shops in Taşlihan held by "two Jews". As for other activities and jobs, a Jew Mirkado was engaged in furniture making, trading watches, while one was even serving in cafeterias. $^{33}$

Some Jews had gained trust of provincial government representatives. Jew Sunbul "did favours for Muslims on higher positions". He worked as money changer (sarraf) in collecting soldiers' salaries during 1765, and he also participated in one strike against Russia. Working there Sunbul earned a fortune and became very rich, but unfortunately he died early. ${ }^{34}$

One of the favourite Jewish activities was related to banking. In the second half of $18^{\text {th }}$ century they were involved into money loans. While Orthodox metropolitan Gavrilo Mihajlović (1740-50) was discharged because of accusations for taking loans from some Jews, other bishops made a debt of 22145 golden coins. Sons of Aron Ćolaković had legally claimed that amount in $1778 .{ }^{35}$ Certainly, money

32 M. Levi, Sefardi u Bosni, pp. 65-66.

33 M. M. Bašeskija, Ljetopis, p. 197, 229, 324, 420.

34 M. M. Bašeskija, Ljetopis, p. 338.

35 V. Skarić, Izabrana djela II, p. 233. 
lending business was not the only local economic activity and naturally all economic activities performed by Jews were not limited only to Sarajevo. Sometimes they reached other parts of Bosnia. In such cases the claims were conducted with help of Muslim friends. In one such mission of collecting assets for the Jews in Krajina in 1797 a banner bearer Avdija Altoka got killed. ${ }^{36}$

Apart from prominent activities widespread among the Jews, at the end of $18^{\text {th }}$ century (March 21, 1786) we find other new occupations among them. They were running pubs or pub related businesses. Of pub keepers residing in "Beytii'l-Yahüd" there were three people: Jakov, Benjamin and Mordohaj. ${ }^{37}$ The location of the inn is not familiar but it can be assumed that it was a part of the complex of Sijavus Pasha's khan and its supporting facility.

Good economic position of individuals made it possible for the Jews to get involved in the process of acquisition of peasant's properties (baştine, çiftlik). ${ }^{38}$ Those çiftliks were in Pofalići, and at the beginning of $19^{\text {th }}$ century $(1818 / 19)$ beneficiaries were Hajdariko, Avram, and Solomon. They had certain tax benefits from those ciftliks that were intended to them by the Bosnian governor - vali in amount of 3 golden coins. It is worth to note that they were the only ones among non-Muslims having that privilege. ${ }^{39}$ This case additionally confirms special status of Jews in local community, where many of them were placed into a group of a few awarded with privilege of tax relieves. Only a small numbers of Muslims were members of that privileged group.

Until the beginning of $19^{\text {th }}$ century most of the trading activities performed by the Jews were located in Taşlihan. The incomplete list of leased shops of Gazi Husrev Bey waqf in the beginning of $19^{\text {th }}$ century $(1820)$ shows how significant role of Jews was in the economic life of the city. However, it also shows at what extant the trade was a source of their existence. There was a significant number of Jews among the renters of waqf shops. They rented 21 warehouses. There were 26 people as renters of storehouses. Twelve people were individually renting the place in such purposes, while seven of them made partnerships. There were those whose economic activities were running very well so they needed even two 
Jews of Sarajevo and Their Place in the Ottoman Society of Bosnia 1109

storehouses. Very interesting peculiarity is that among the renters of storehouses we found two women. Merchant shops were used by significantly more individuals than the ones belonging to waqf. There were 44 of them as renters of these places. Thirteen of the shops were rented by partnerships, which meant at least 26 joint merchants, while 18 of them were engaged in trade individually. They had 32 shops rented for them. Outside of this complex, three more shops were rented by the Jews. It seems that the places were smaller because the leaseholds were smaller. ${ }^{40}$ Even though the list is not complete, it still gives a certain possibility to make estimations and conclusions.

In relation to the total number of Jewish households, it was noted that 30 households lived from trading businesses. If we observe that number in relation to the total number of adults (above 18 years), we can conclude that $22 \%$ of merchants are Jewish. Again, we have to point to two important facts. The list referred only to shops leased by Gazi Husrev-beg's waqf which furthermore was not complete. Therefore, the percentage we stated above could be considered to be the lower limit because we can assume that there were merchants outside of that place and in other places. We can conclude that the participation of Jews in trading businesses was fairly high, compared to their total percentage in population. And if we observe their participation in households, it was 6\% in Sarajevo, yet if we observe the number of men then the percentage grows to $9 \%$, which was a more realistic estimation of Jewish share in population of Sarajevo. ${ }^{41}$ According to other documented cases in this source, we can see that they use $30 \%$ of storehouse and $16 \%$ of shop space. Unfortunately, from this source it is not known what the object of their trades was. It was probably trade of clothes, cloth materials or craft products. Jews were also involved into grain trading, which was mentioned in a litigation of claiming debt. Mitar son of Luka from Slatina near Sarajevo; claimed 800 of golden coins from Jew "Lizića Bihora", that he owed him for grain in "previous four years" (1841-1845). He avoided the payment, at least temporarily, by escaping to Jerusalem (Kuds-i Şerif) only two days before a warrant for his arrest and judicial enforcement for paying debts was issued. ${ }^{42}$

In the middle of $19^{\text {th }}$ century, trade crisis in Sarajevo hit all the merchants and

$40 \mathrm{GHb}, \mathrm{R} 180$.

41 In Sarajevo there were about 70\% of Muslims, $20 \%$ of Christians, $9 \%$ of Jews and 1\% of Gypsies.

42 Sidžil Mula Muhameda Mestvice, OIS; ANU BiH, 237, 21. 
especially Jews. Many Jewish merchants got bankrupt at that time and could not repay their merchant debt to their creditors from Trieste. The claims had been requested through diplomacy, and for those needs they set up a Commercial court which had 5 members: two Muslims, two Christians and one Jew. ${ }^{43}$

\section{Conclusion}

After the first accounts in 1557, 1565 and 1566, Ottoman sources did not give any information about Jewish population in Sarajevo. Sources from the second half of $16^{\text {th }}$ century from Dubrovnik, and especially after 1570, indicated increased activities of Jews in economic life of Sarajevo. Even though there are not enough data upon which it would be possible to reliably follow the demographic growth of the Jews, we tried to show the dynamics of demographical growth of the community until the end of the Ottoman rule based on available written sources. The sources are poor; yet coming from different provenance, they show no significantly huge differences. Even though incomplete, much of the information they bring are highly matching each other. However, they were complete in $19^{\text {th }}$ century and show the percentage of the Jews in confessional structure of Sarajevo. Their share reached $9 \%$ of urban population.

Even though Sijavuş Pasha's khan was often recorded as the only residing place of the Jews, Evlija Çelebi documented two more streets with Jewish residents in $17^{\text {th }}$ century. Two locations recorded by Evlija Çelebi were probably two collective lodging facilities, in Sagrakdži hadži Mahmud's mahala - Mahmud's khan, and Sijavuş Pasha's khan. In $18^{\text {th }}$ century Jews were mentioned individually living around many different streets such as Bardakčije, Careva mahala (Padišahova mahala), Kasim Kjatibova mahala. By the end of $18^{\text {th }}$ century, another location was registered as collective lodging where Jews resided was Buzadži Hadži Hasan's street. And by the $19^{\text {th }}$ century, Jews were concentrated in nucleus of economic activities of Sarajevo, within compact space of seven streets.

In the documented sources, trading was recorded as the main business activity of the Jews, but it is also worth to note the broad circle of interests and businesses they were engaged in. Some were, unexpectedly, running pubs or producing furniture. One analysis of a source from the beginning of $19^{\text {th }}$ century shows high share of trade in businesses of Jews from Sarajevo. Even incomplete, the source 
Jews of Sarajevo and Their Place in the Ottoman Society of Bosnia 111

shows that at least $22 \%$ of the Jews in Sarajevo were engaged in trading. If we take into consideration that the percentages covered only small number of shop renters, it could be expected to see larger numbers and percentages of actual trading businessmen.

\section{BIBLIOGRAPHY}

\section{Unpublished Sources}

Gazi Husrev-begova biblioteka, Sarajevo.

GHb, Sidžil 1

GHb, Sidžil la.

GHb, Sidžil 2

GHb, Sidžil 25

GHb, Sidžil 59

GHb, R. 180

Cumhurbaşkanlığı Devlet Arşivleri Başkanlığı Osmanlı Arşivi, İstanbul.

BOA, MAD, 1439.

BOA, MAD, 1214.

BOA, TD, 379.

\section{Published Sources}

Opšrini popis Bosanskog sandžaka iz 1604, Sv. I/1, Obradio: Adem Handžić, Sarajevo 2000.

Evlija Čelebija, Putopis, odlomci o jugoslovenskim zemljama, (Preveo, uvod i komentar napisao Hazim Šabanović, Sarajevo 1979.

Salih Sidki Hadžihuseinović, Muvekkit, Povijest Bosne 1, Sarajevo 1999.

Mula Mustafa Mestvica, Popis uzajamnog jamčenja stanovništva u Sarajevu iz 1841. godine, (preveo s turskog: Derviš Korkut) Sarajevo 1970.

Mula Mustafa Bašeskija, Ljetopis, Sarajevo 1968.

\section{Books - Articles}

Batinić, Mijo V., "Nekoliko priloga k bosanskoj crkvenoj povijesti", Starine $\mathcal{F A Z U ~}$ 
XVII, Zagreb 1885, pp. 77-150.

Bejtić, Alija, "Sijavuš-pašina daira", Prilozi za proučavanje istorïe Sarajeva, Godina II, Knjiga II, Sarajevo 1966, pp. 61-89.

Bejtić, Alija, "Jevrejske nastambe u Sarajevu", Spomenica, 400 godina od dolaska fevreja u Sarajevo, Jevrejska zajednica Sarajevo 1967, pp. 23-32.

Horvat, Karlo, "Novi historijski spomenici", Glasnik Zemaljskog muzeja, XXI (1909), Sarajevo 1909, pp. 1-104.

Jelavić, Vjekoslav, "Doživljaji Francuza Poullet-a, na putu kroz Dubrovnik za Bosnu, (godine 1658)", Glasnik Zemaljskog muzeja 1908, Sarajevo 1908, pp. 56-71.

Jelenić, Julijan, "Spomenici kulturnoga rada bosanskih franjevaca, Starine $X X X V$, (1918), Zagreb 1916.

Kaluđerčić, Slavko, "Iz istorije Sarajeva", Glasnik Jugoslovenskog profesorskog društva, knj. XiX, sv. 11-12, Beograd 1939, pp. 805-853.

Korkut, Derviš M., Mestvičina ćefilema iz 1841., Prilozi za proučavanje istorïje Sarajeva, II, Sarajevo 1966, pp. 103-117.

Levi, Moric, Sefardi u Bosni, Beograd 1969.

Nezirović, Muhamed, "Historija Bosanskih Jevreja Moše (Rafaela) Atijasa - Zeki Efendije”, Prilozi, Institut za istoriju, 29 (2000) Sarajevo 2000, pp. 245-260.

Pejanović, Đorđe, Stanovništvo Bosne i Hercegovine, Beograd 1955.

Skarić Vladislav, Sarajevo i njegova okolina od najstarijih vremena do austrougarske okupacïje, Sarajevo 1937.

Spitzer, ShlomoJ. - Komoróczy Géza, Heber Kútforrások Magyarország és a magyarországi zsidóság történetéhez a kezdetektól 1686-ig, MTA Judaiszitakai KutatócsoportOsiris Kiadó, Budapest 2003.

Sućeska, Avdo, "Da li su sarajevski jevreji bili muaf", Godišnjak Pravnog fakulteta, XXIII/1975, Sarajevo 1975, pp. 191-201.

Sućeska, Avdo, "Neke osobenosti u procesu čiflučenja u Bosni i Hercegovini u XVIII stoljeću”, Godišnjak Pravnog fakulteta, XXI, Sarajevo 1973, pp. 331-341.

Tadić, Jorjo, "Doprinos Jevreja trgovini sa dalmatinskim primorjem u XVI i XVII vijeku”, Spomenica 400 godina dolaska Jevreja u BiH, Sarajevo 1967, pp. 33-47. 
Jews of Sarajevo and Their Place in the Ottoman Society of Bosnia 1113

Tadić, Jorjo, Fevreji u Dubrovniku do polovine XVII stoljeća, Sarajevo 1937.

Younis, Hana, "Skice porodičnog života u Sarajevu posljednjih decenija osmanske vladavine", Prilozi, 36, Sarajevo 2007, pp. 33-68.

Zlatović, Stipan, "Izvještaj o Bosni god 1640. O. Pavla iz Rovinja”, Starine 23, 23 (1890) Zagreb 1890, pp.1-38.

F.(ran) M.(ilobar), "Dva savremena izvještaja o Bosni iz prve polovine XVII. stoljeća”, GZM, XVI/1904, Sarajevo 1906, pp. 251-266.

Štatistika miesta i pučanstva Bosne i Hercegovine, Sarajevo 1880. 
